\title{
Effect of Malting on Chemical Composition and Protein Invitro Digestibility of Three New Varieties of Sorghum Grains
}

\author{
Edafe Valentino Okporo ${ }^{1}$, Danladi Amodu Ameh ${ }^{2}$, Abdullahi Balarabe Sallau ${ }^{3}$, D.A.Aba ${ }^{4}$ \\ ${ }^{1,2}$ Department of Biochemistry, Faculty of Science, Ahmadu Bello University, Zaria, Kaduna State Nigeria
}

\begin{abstract}
The changes in chemical composition andInvitro protein digestibility content before and after germination of three new sorghum varieties, named 'Samsorg41', 'Samsorg42', and 'Samsorg43' were investigated. The chemical composition concluded including crude protein, oils, crude fiber, dietary fiber soluble and insoluble ash, and carbohydrate. Crude protein, oil and fiber content was increased by malting. Processed 'Samsorg 41' was the highest variety in crude protein, oil and crude fiber content $(9.8 \%$, $9.89 \%$ and 2.85). Processed 'Samsorg 43' was the lowest variety in ash, and carbohydrate. Invitro digestibility ranged from $87.6 \%$ to $90 \%$ in raw sorghum. Invitro digestibility was higher in processed 'Samsorg42' than other varieties (90\%). The evidence would seem to support the suggestion that the simple technology of malting offers a means by which to improve the quality and digestibility of sorghum protein.
\end{abstract}

Keywords: malting, chemical composition, digestibility, processing, sorghum

\section{Introduction}

Sorghum is a cereal native to sub-Saharan Africa and grows well in temperate and tropical areas of the world. Nigeria is the number one producers of sorghum in the world and Africa respectively followed by United States and India. International crop research institute of the semi-arid tropics (ICRISAT, 2010). In Nigeria, sorghum is produced in dry land regions and production is still on subsistence bases, commonly grown cultivars include both improved and local cultivars (FAO, 2005).

Germination has been proven to be a process that helps improve the nutrition of sorghum seeds as it can help in components, including hydrolytic enzymes synthesis such as phytate reduction and some flavonoids components. Hence germination of sorghum is very important in preparing for the development of food with low viscosity and high energy. (Dicko et al., 2006).

There are a range of chemical and structural changes that take place within the cereal grain through the hydroponic growing process. Activation of enzymes within the grain leads to hydrolysis of proteins, carbohydrates and lipids into their simpler components (Sneath and McIntosh, 2003). Chavan and Kadam (1989) stated that, sprouting grains causes increased activities of hydrolytic enzymes, improvements in the contents of total proteins, fat, certain essential amino acids, total sugars, B-group vitamins, and a decrease in dry matter, starch and anti-nutrients. The increased contents of protein, fat, fiber and total ash are only apparent and attributable to the disappearance of starch.

Processing methods, such as soaking, sprouting and cooking has been found to improve the nutritional value of plant grains (Jirapa et al., 2001). Sprouting is one of the processing methods that improve the in vitro protein digestibility and minerals availability by reduction of antinutritional factors (Tannin and phytate).

\section{Materials and Methods}

\section{Source of raw material}

The sorghum grains that will be used for this study will be obtained from IAR. The three varieties of the sorghum that will be used include (using local names) SAMSORG42, 43 and 44 . The sorghum varieties will be authenticated by a seed breeder at the institute of agricultural research, Ahmadu Bello University Zaria, Kaduna state, Nigeria.

Grain sorghum kernels from each sorghum variety will be cleaned by first manually sorting to remove deformed, small broken and immature kernels, dust, sand, stones, and other foreign materials. The kernels will then be quickly washed by immersion in cold tap water in a 20 - L bucket, stirred by hand and screened out of the water. Following washing the kernels will be dried at room temperature using standard procedures. After drying, kernels will be kept in plastic bags and held at room temperature, before grain quality tests are performed for each of the three sorghum varieties.

\subsection{Malting procedure}

Kernel (also in triplicate) from each of the Samsorg varieties were placed in bags made of porous canvas. The bags containing kernels was immersed in tepid tap water contained in 20- L plastic buckets and then placed in a controlled chamber, set and maintained at $27{ }^{\circ} \mathrm{C}$ and $98 \%$ relative humidity to begin the steeping phase (Mella, Onesmo 2011). During the steeping stage, the steeping water was drained and replaced with fresh water every 8 hours for 2 days. After steeping, the kernels were removed out of the bags, blotted with towels to remove surface water and returned to the bags. The bags with kernels were then placed in a controlled chamber at room temperature and $98 \%$ relative humidity to begin the germination process. During the 72hours germination, the covering papers was lifted every 12 hours and the surface of the kernels was being sprayed with tap water. Following germination, the bags with the kernels was then been transferred to a forced air drying oven maintained at $50{ }^{\circ} \mathrm{C}$ and held for 24 hours 


\section{International Journal of Science and Research (IJSR) \\ ISSN (Online): 2319-7064}

Index Copernicus Value (2013): 6.14 | Impact Factor (2015): 6.391

afterwards, kernels was left on the sheets of paper to cool at room temperature and thereafter all rootlets and shoots was removed from the malted kernels by rubbing vigorously between the hands, and then separated by shifting through a $2.5 \mathrm{~mm}$ sieve. Malted kernels were milled with a Quadrumat Jr. Laboratory mill (Brabender, Duisburg Germany) to get the samples (Mella, 2011).

\subsection{Proximate Analysis}

All Samsorg samples was analyzed for raw and malted. Moisture content was determined by drying in a Brabender Moisture Tester oven (Brabender Instruments Inc., NJ) at $135^{\circ} \mathrm{C}$, according to AOAC (1984) approved method 7.007. Nitrogen content was estimated by the Kjeldahl nitrogen method 2.057 (AOAC, 1984). Protein content was calculated by multiplying \% nitrogen by 6.25 . Crude fat was estimated by the chloroform-methanol extraction method described by Phillips, et al., (1997), which is a modification of AOAC (1990) method 983.23. Crude fiber analysis was determined using (AOAC 1984). Ash content was determined by decomposition in a muffle furnace at $550{ }^{\circ} \mathrm{C}$ for 12 hours according to method 7.009 (AOAC, 1984), Determination of dietary fibre using enzymatic gravemetric method (1992).

\subsection{In vitro Protein Digestibility}

In vitro protein digestibility of the samples was measured according to the method described by Monjula \& Johon (1991), in which a pepsin digestion method was used in the determinations. The digestible protein was analyzed for nitrogen using micro Kjeldahl procedure (AOAC, 1990) and expressed as a percent of the total $\mathrm{N}$.

\section{Results and Discussion}

\subsection{The protein Invitro Digestibility of Raw Sorghum Flour (RSF) and Malted Sorghum Flour (MSF) are shown in Table 4.3}

A major objective of malting is to promote the development of hydrolytic enzymes, which are not present in the nongerminated grain. There was a significant increase in the protein Invitro digestibility, malting significantly $(p<0.05)$ improved the in vitro digestibility and the quality of the sorghum protein, which increased with increasing malting time as recorded by Donaldson, A.S. (2010). The evidence would seem to support the suggestion that the simple technology of malting offers a means by which to improve the quality and digestibility of sorghum protein J. Dewar (1995), Protein digestibility studies conducted showed that processing increase protein in vitro digestibility as was stated by Pederson et al., (2000).
3.2 The proximate composition of Raw Sorghum Flour (RSF) and Malted Sorghum Flour (MSF) are shown in Table 4.2.

The moisture content ranged from 5.37 to $7.15 \%$. Significant $(\mathrm{P} \leq 0.05)$ increase was observed in moisture content of the processed flours compared with the control. The highest in moisture content was observed in processed Samsorg 42 $(7.15 \%)$ similar result was gotten by Sale, (2010), The increase in moisture content of processed flours may be due to the water added before processing Report by Trubey et al., (1969) indicated an increase in fresh weight of barley sprouted for 3 and 6 days. Ash content of sorghum flour was $1.5 \%, 1.24$ and 1.2 it was significantly $(\mathrm{P} \leq 0.05)$ decreased after sprouting to $1.23,1.16$ and $1.1 \%$, respectively, and fibre content also increased from $1.03,0.77$ and 0.86 to 2.85 , 2.53 and 2.13, respectively. This result is in agreement with Moharram and Youssef (1995), mentioned that ash and crude fiber contents of sorghum grains differ from 1.30-3.40 and $0.90-4.20 \%$, respectively. Pontieri et al. (2011) who found that ash content ranged from 0.77 to $1.39 \%$ in different sorghum varieties. Morover, Chung et al. (2011) found that 1.43 to $1.92 \%$. On the other hand, Hamad (2007) reported that sorghum ash ranged from 1.51-2.06\%. After treatments, ash content was decreased than raw sorghum. These results are in agreement with Okrah (2008) who found that ash content of germinated sorghum varied from 0.28 $1.70 \%$. Gernah et al. (2011) found that germination of grains decreases ash content. While, Mubarak (2005) reported that germination and cooking processes caused significant decreases in ash content the decrease in ash content of sprouted sorghum may be due to the consumption of ash during the growth of the germ.

There was a significant increase crude protein and oil content, results are in agreement with Okrah (2008) who found that oil content of germinated sorghum varied from $1.44-2.57 \%$. Afify et al. (2012c) mentioned that Sorghum bicolor varieties could be additional sources of edible oil due to presence of clinically important saturated and high concentration of unsaturated fatty acids. Moreover, Hamad (2007), Okrah (2008) and Chung et al. (2011) reported that sorghum protein content varied from 9.06 to $18.58 \%, 8.32$ to $11.82 \%$ and 11.23 to $13.42 \%$, respectively.

The carbohydrate content of control sample flour was found to be $77.08-77.28 \%$, and sprouted in range of 71.74 74.18 result in agreement to $(74.35 \%)$ reported by sale, (2010). The decrease in carbohydrate content of sprouted sorghum flours may be due to utilization of some sugars during the growth metabolic activity. 


\section{International Journal of Science and Research (IJSR) \\ ISSN (Online): 2319-7064}

Index Copernicus Value (2013): 6.14 | Impact Factor (2015): 6.391

Table 1: Comparism of the proximate composition of raw and processed (malted) sample of the new varieties of

\begin{tabular}{|c|c|c|c|c|c|c|}
\hline SAMPLES & $\begin{array}{c}\text { RAW } \\
\text { SAMSORG } 41\end{array}$ & $\begin{array}{c}\text { RAW SAMSORG } \\
42\end{array}$ & $\begin{array}{c}\text { RAW } \\
\text { SAMSORG } \\
43\end{array}$ & $\begin{array}{c}\text { MALTED } \\
\text { SAMSORG } \\
41\end{array}$ & $\begin{array}{c}\text { MALTED } \\
\text { SAMSORG } \\
42\end{array}$ & $\begin{array}{c}\text { MALTED } \\
\text { SAMSORG } \\
43\end{array}$ \\
\hline Moisture (\%) & $5.37 \pm 0.10^{\mathrm{a}}$ & $5.98 \pm 0.03^{b}$ & $5.58 \pm 0.24^{\mathrm{a}}$ & $6.89 \pm 0.35^{\mathrm{c}}$ & $7.15 \pm 0.27^{\mathrm{c}}$ & $6.9 \pm 0.04^{\mathrm{c}}$ \\
\hline Ash (\%) & $1.5 \pm 0.10^{\mathrm{a}}$ & $1.24 \pm 0.08^{\mathrm{a}}$ & $1.2 \pm 0.10^{\mathrm{a}}$ & $1.23 \pm 0.36^{\mathrm{a}}$ & $1.16 \pm 0.22^{\mathrm{a}}$ & $1.1 \pm 0.20^{\mathrm{a}}$ \\
\hline Lipid (\%) & $8.09 \pm 0.16^{\mathrm{a}}$ & $8.13 \pm 0.24^{\mathrm{a}}$ & $8.73 \pm 0.66^{\mathrm{ab}}$ & $9.8 \pm 0.48^{\mathrm{c}}$ & $8.8 \pm 0.25^{\mathrm{abc}}$ & $9.4 \pm 1.08^{\mathrm{bc}}$ \\
\hline Protein $(\%)$ & $7.16 \pm 0.28^{\mathrm{a}}$ & $6.8 \pm 0.23^{\mathrm{a}}$ & $7.21 \pm 0.30^{\mathrm{a}}$ & $9.89 \pm 0.48^{\mathrm{c}}$ & $8.71 \pm 0.00^{\mathrm{b}}$ & $8.73 \pm 0.03^{b}$ \\
\hline Crude Fiber (\%) & $1.03 \pm 0.05^{\mathrm{a}}$ & $0.77 \pm 0.05^{\mathrm{a}}$ & $0.86 \pm 0.33^{\mathrm{a}}$ & $2.85 \pm 0.17^{\mathrm{d}}$ & $2.53 \pm 0.07^{\mathrm{c}}$ & $2.13 \pm 0.10^{\mathrm{b}}$ \\
\hline CHO (\%) & $77.8 \pm 0.12^{\mathrm{c}}$ & $77.08 \pm 0.39^{\mathrm{c}}$ & $77.28 \pm 0.7^{\mathrm{c}}$ & $72.19 \pm 0.52^{\mathrm{a}}$ & $74.18 \pm 0.75^{b}$ & $71.74 \pm 1.22^{\mathrm{ab}}$ \\
\hline Protein Invitro (\%) & $87.62 \pm 0.24^{b}$ & $90.66 \pm 0.19^{\mathrm{c}}$ & $86.37 \pm 0.10^{\mathrm{a}}$ & $93.42 \pm 0.25^{\mathrm{d}}$ & $95.52 \pm 0.39^{\mathrm{e}}$ & $93.40 \pm 0.16^{\mathrm{d}}$ \\
\hline
\end{tabular}

Values are mean of triplicates $\pm \mathrm{SD}$ for chemical composition and invitro protein digestibility

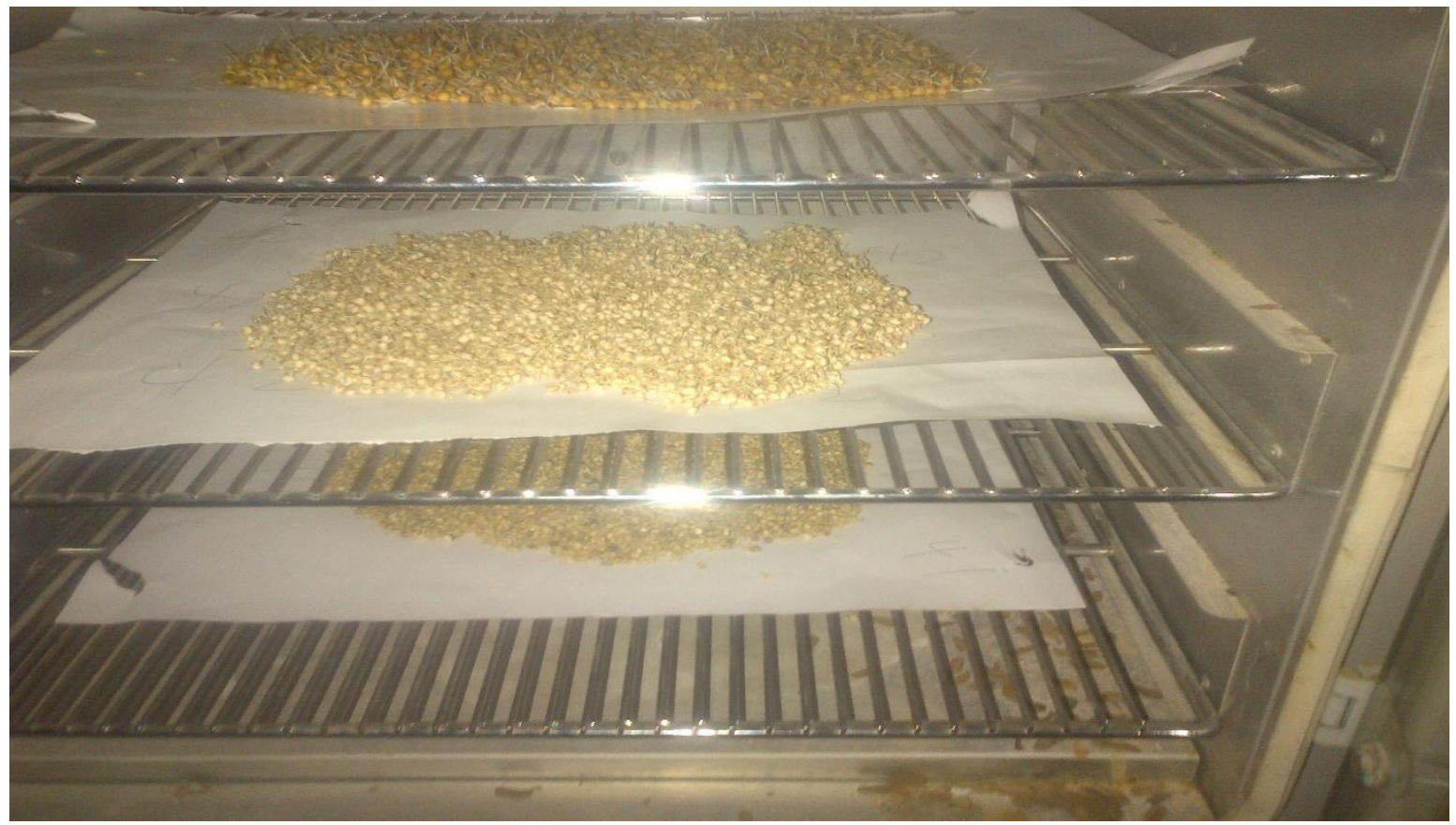

Figure 1: Oven drying of Samsorg 41, 42 and 43

\section{Conclusions}

The technology of malting could also be applied to relatively poor rural communities where nutritional enhancement would appear to be most required. Malted sorghum, with improved protein quality and digestibility could be used in the formulation of weaning foods. In rural communities the first weaning foods are generally gruels made from cereals with low nutritional density and energy levels. Introducing a small amount of malted sorghum flour "power flour" to the thick porridge gruel will quickly liquefy it without reducing, perhaps even increasing the nutritional value and make it more acceptable and more easily digested by the infant.

\section{Potential Conflicts of Interest}

If there is no conflict, "I Edafe Valentino Okporo author of this paper state there is no conflict of interest, this paper has not been published by anyone before."

\section{Acknowledgments}

I give thanks to God who gives us knowledge and life to live. I extend my sincere thanks to all the people who supported and made it possible for me to reach this milestone in my life. I thank my Advisor, Prof. D.A Ameh a father to all, for having faith in me and encouraging me throughout my studies and for his excellent guidance, suggestions and constructive criticisms during the research work and preparation of this manuscript. I would also like to express my sincere thanks to my team of supervisors Dr. A.B. Sallau and Prof. D.A. Aba. my parents $\mathrm{Mr}$ and Mrs Clifford Okporo and my Guardian Engr. Mrs. G.O. Erhimona for their prayers and continuous support. Many thanks also go to all lecturers and supporting staff of the Department of crop science, Ahmadu Bello University, Zaria for their help, in particular Ibrahim the Lab. Technician food science laboratory Institute of Agricultural research for his guidance in laboratory analyses. I extend my gratitude to the other members of my committee: Prof. Aba, Prof. Mary and Dr. Ibrahim sorghum breeders IAR, for their excellent guidance on the botanical aspects of Samsorg 41, 42 , and 43 .

\section{References}

[1] Afify AMR, Rashed MM, Ebtesam AM, El-Beltagi HS (2011b). Effect of gamma radiation on protein profile, protein fraction and solubility of three oil seeds. Not Bot Horti Agrobo 39(2):90-98.

[2] AOAC 1984. Official Methods of Analysis, 14th ed. Association of Official Analytical 


\section{International Journal of Science and Research (IJSR) \\ ISSN (Online): 2319-7064}

Index Copernicus Value (2013): 6.14 | Impact Factor (2015): 6.391

[3] AOAC 1990. Official Methods of Analysis, 15th ed. Association of Official Analytical

[4] Chavan, J. K. and Kadam, S.S. (1989). Nutritional improvement of cereals by sprouting. Creatical Rev. Food Sci. Nutrition., 28:401-437.

[5] Chung M, Kim E, Yeo M, Kim S, Seo M, Moon H (2011). Antidiabetic effects of three Korean sorghum phenolic extracts in normal and streptozotocin-induced diabetic rats. Food Res Inter 44:127-132.

[6] Dewar, J; Joustra, S.M; and Taylor, J.R.N. 1995. Accepted methods of sorghum malting and Brewing Analysis. SIR Food Sci. and Technology Pretoria, south Africa.

[7] Dicko MH, Gruppen H, Traoré AS, Voragen AGJ, van Berkel WJH (2006). Sorghum grain as human food in Africa: relevance of content of starch and amylase activities. Afr J Biotech 5(5):384-395.

[8] Donaldson, A.S. Steeping and sorghum malting. MSc dissertation. University of Pretoria (1999).

[9] FAO, (1995). Sorghum and Millet in Human Nutrition. Food and Nutrition Series. No. 27. Food and Agriculture Organisation, Rome/WHO p. 333 Retrieved on July 12, 2005 from http://www.fao.org/ DOCREP/TO818e/TOP18Eoo.html

[10] Gernah DI, Ariahu CC, Ingbian EK (2011). Effect of malting and lactic fermentation on some chemical and functional food use. Food Chem 98:32-38.

[11] Hamad RME (2007). Preliminary Studies on the Popping Characteristics of Sorghum Grains. M.Sc. Thesis, Sudan Academy Sci., Al-Zaiem Al-Azhari Univ., Sudan, 90. p.

[12] "Industrial Utilization of Sorghum in India" (PDF). ICRISAT, India. December 2007."Sorghum". United States Grain Council. November 2010.

[13] Jirapa. P., Normah, H., Zamaliah, M.M., Asmah. R \& Mohamad, K (2001). Nutritional quality of germinated cowpea flour (Vignaunguiculata) and its application in home preparing weaning foods. plant foods for human Nutrition. 56, 203-216.

[14] Mella, Onesmo N.O., (2011). "Effects of Malting and Fermentation on the Composition and Functionality of Sorghum Flour" Dissertations \& Theses in Food Science and Technology. Paper 12

[15] Moharram YG, Youssef AMA (1995). Sorghum grain and quality of its edible products, 37:111-146 p. In: Charalambous G (Ed.). Food Flavors: Generation, Analysis and Process Influence, Developments in Food Science, Elsevier Applied Science.

[16] Okrah SG (2008). Screening of Six Local Sorghum Varieties for their Malting and Brewing Qualities. M.Sc. Thesis, Kwame Nkrumah Univ. Sci. Tech., Ghana, $87 \mathrm{p}$.

[17] Pontieri P, Di Fiore R, Troisi J, Bean SR, Roemer E, Okot J, Alifano P, Pignone D, Giudice LD, Massardo DR (2011). Chemical composition and fatty acid content of white food sorghums grown in different environments. Maydica 56:1-7.

[18] Sneath, R. and McIntosh, (2003). Review of hydroponic fodder production for beef cattle. Queens land Government, Department of primary Industries, Dolby, Queensland. Pp. 12-67.

[19] Sule Sale, (2010). Nutritive value of white kaura sorghum (sorghum bicolor l.moench) grains and sprouts and their utilization by goats, Department of animal science, faculty of Agriculture, Ahmadu Bello university, Zaria Nigeria PP 5. 